\title{
Research Article: Influence of post-harvest chemical treatments on shelf-life of carnation (Dianthus caryophyllus L.)
}

\section{KRISHNAMOORTHY, V. MYTHILIPRIYA, G. POOVARASAN AND S. SANGAVI}

Article Chronicle:

Received :

05.07.2017;

Accepted :

22.07.2017

KeY Words:

Post harvest

chemicals, Variety,

Parameters

Author for correspondence :

\section{KRISHNAMOORTHY}

Department of

Horticulture,

Vanavarayar Institute of Agriculture, POLLACHI

(T.N.) INDIA

Email:plantdoctorkrishna@ gmail.com

See end of the article for authors' affiliations
SUMMARY : A Lab experiment was conducted at Vanavarayar Institute of Agriculture, Pollachi, Tamil Nadu with an objective of studying the influence of post-harvest chemical treatments on shelf life of carnation. The experiment was carried out during 2015 - 2016 in a Completely Randomized Design replicated thrice. The experiment consisted of ten treatments and two varieties of carnation flowers (Red and White). Three different chemicals like boric acid, sucrose and calcium chloride with three different concentration mixtures of $0.1 \%, 0.2 \%, 0.3 \%, 1 \%, 2 \%, 3 \%$ and $4 \%$ then control using distilled water were investigated in this study. The study revealed that there were significant differences in vase life of carnation varieties due to application of the different chemical mixtures. The Red colour variety combination with the treatment $\mathrm{T}_{3}$ [Boric acid $(2 \%)+$ Sucrose $(3 \%)+$ Calcium chloride $\left.(0.3 \%)\right]$ were recorded higher mean values for all the parameters like weight of the flower $(14.89 \mathrm{~g})$, diameter of the flower $(4.9 \mathrm{~cm})$, water uptake of the flower $(31 \mathrm{ml})$ and vase life of the flower ( 9 days $)$ which was followed by the combination White colour variety + treatment $\mathrm{T}_{5}$ [Boric acid $(3 \%)+$ Sucrose $(2 \%)+$ Calcium chloride $(0.2 \%)$ ] with the value of weight of the flower $(14.1 \mathrm{~g})$, diameter of the flower $(4.9 \mathrm{~cm})$, water uptake of the flower $(29 \mathrm{ml})$ and vase life of the flower (8.5days).

How to cite this article : Krishnamoorthy, C., Mythilipriya, V., Poovarasan, G. and Sangavi, S. (2017). Influence of post-harvest chemical treatments on shelf-life of carnation (Dianthus caryophyllus L.). Agric. Update, 12(TECHSEAR-1) : 92-96; DOI: 10.15740/HAS/AU/12.TECHSEAR(1)2017/92-96. 